\title{
Evoke and $A$ Thesaurus of Old English in the Old English Classroom
}

\author{
Kees Dekker \\ Department of English, University of Groningen, \\ Groningen, Niederlande \\ c.dekker@rug.nl
}

\begin{abstract}
The use of Evoke and the Thesaurus of Old English (TOE) in the classroom at beginners' level is not self-evident, since both are electronic tools designed to facilitate lexicological research for more advanced users. Nonetheless, there is an advantage in acquainting students with modern electronic tools allowing relevant, piecemeal investigations into the lexicon. This contribution focuses on the usage of Evoke in the classroom, suggesting the types of assignments that may be designed for this purpose and exploring further possibilities.
\end{abstract}

\section{Keywords}

Evoke - teaching - didactics

\section{$1 \quad$ Introduction}

If Ælfric of Eynsham had designed the digital platform Evoke (Stolk, 2018) a little more than a thousand years ago, he might have called it Plurivoke. For, as Ælfric describes in his Grammatica - a grammar of Latin written in Old English - in the section on nouns: "some are sinonima, these are plurivoca; they mean a single thing with multiple appellations, just as ensis is sword, 
gladius is sword and mucro is sword; terra is earth and tellus is earth." ${ }^{1}$ The importance of synonyms was known to the Anglo-Saxons, whose educational system involved class glossaries (also known as topical glossaries), which listed together terms from a specific topical field. The use of class glossaries reached back to the genre of hermeneumata: combinations of alphabetical glossaries, class glossaries and small conversational texts known as colloquies, found as appendices to grammars during the late classical period to help pupils who spoke Latin to learn Greek. The earliest examples of such schoolbooks are the so-called Hermeneumata pseudo-Dositheana (Lendinara, 1999: 9-11; Dionisotti, 1982: 91). In Ælfric's Glossarium, which follows the Grammatica in some of the manuscripts, the complexities of both the Latin and the Old English lexicon become clear: Old English eorðe is known as tellus or terra (the same example as in the Grammatica), but molde 'the ground' is humus (ed. Zupitza, 1880: 297). Very appropriately, 'the sea' is the next concept. Old English see is mare or aequor in Latin, but pelagus is the Latin word for Old English widsce 'open sea, ocean'; Latin oceanum is rendered in Old English as garsecg 'lit. spear-man', a compound of uncertain etymology. ${ }^{2}$ The lexemes for 'sea' on both sides of the linguistic divide give us important information about how such an omnipresent concept as the sea or ocean was worded by the Romans and the Anglo-Saxons, what distinctions they made, what images they may have used to depict the sea in words. Early medieval commentaries on synonymy, such as Isidore of Seville's De differentiis verborum (ed. and trans. Codoñer, 1992), show the importance which was attached to the sometimes minute distinctions between terms for similar concepts.

Anyone who is teaching Old English nowadays and whose curriculum includes, of course the Seafarer, or Andreas, or Beowulf, or even Exodus, in which, after the Egyptian Faraoh has entered the Red Sea, "holmweall astah, merestream modig" (1l. 468b-469a), ${ }^{3}$ will recognise the potential of investigating the vocabulary concerning the sea in the light of these texts. How many lexemes for 'sea' are there in Old English, and how should they be semantically arranged? For this kind of question, the data from $A$ Thesaurus of Old English $(T O E)$ viewed through the lense of Evoke are vital. Evoke reveals that within the тов category "O1.01.03.01.02 sea/ocean", there are no fewer than 177 Old English lexemes, $85 \%$ of them nouns. Among the subordinate concepts, $27 \%$ of these lexemes evoke the meaning of 'wave', while another $21 \%$ concern the

1 "sume sind SINONIMA, ID SVNT PLURIVOca, ða getacenjað an ðing mid menigfealdre clypunge, swaswa ys ensis swurd, gladius swurd, mucro swurd; terra eorðe, tellus eorðe" (Zupitza, 1880: 12).

2 Perhaps the location of the spear man Triton, Poseidon or Neptune, see DOE, s.v. garsecg.

3 Translated as "the seawall ascended, the brave sea-current", by Anlezark (2011: 237). 


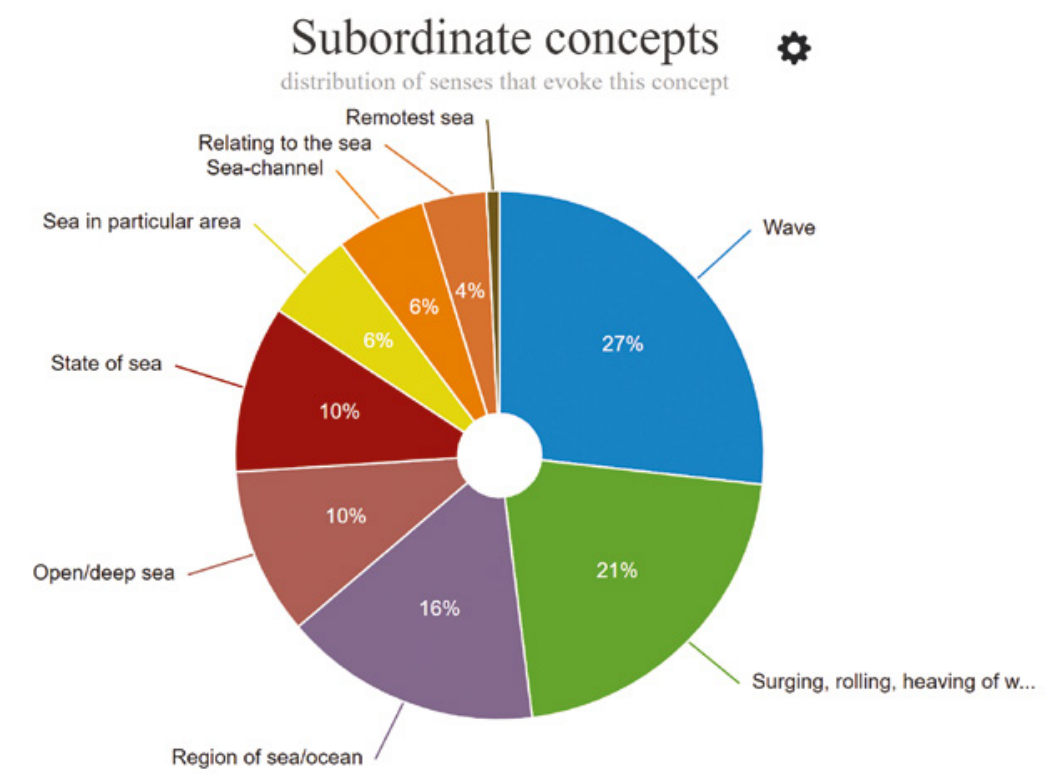

FIGURE 1 Evoke pie chart showing the distribution across the subordinate concepts of the TOE category "01.01.03.01.02 sea/ocean"

surging, rolling or heaving of the waves. $22 \%$ describe sea or ocean in terms of region or area; $4 \%$ touch on its remoteness; $10 \%$ denote an open, deep sea, while $6 \%$ talk about sea in terms of a channel (see Figure 1 ).

It was with this kind of example in mind that the idea arose to explore the possibilities of Evoke in the classroom. ${ }^{4}$ In this article, I should like to share some of my experiences and explore what technology such as the Old English Thesaurus and Evoke can contribute to the teaching of Old English in a classroom situation.

In the last two years I have integrated Evoke in a seven-week module titled "Language and Culture of Anglo-Saxon England", for second- and third-year BA Students of English Language and Culture, at the University of Groningen. The

4 This idea developed during a workshop titled "EASE: Exploring Anglo-Saxon Eloquence" on 1 February, 2019. Thijs Porck had been experimenting with the TOE and Evoke in a workshop titled "Digital resources for the 21st-century Anglo-Saxonist" with advanced students; I then suggested trying out Evoke in a module with students who are taking Old English for the first time, in the third year of the ва. 
module offered two seminars of two hours per week. The course books were Bruce Mitchell and Fred Robinson's Guide to Old English (2011) for grammar and texts and the Cambridge Companion to Old English Literature (eds. Lapidge and Godden, 2013) for essential background reading. Students prepared by studying the Old English grammar and the contributions to the Cambridge Companion. In class, the students translated fragments of texts and gave presentations on literary and cultural topics. The assessment in the form of a written exam with translation assignments and an essay tested the following learning outcomes: "Upon successful completion of the module, students are able to (1) understand Old English and translate Old English texts into Modern English with the help of a grammar and a dictionary; (2) contextualize the Old English texts under investigation; (3) conduct independent research on any topic related to Anglo-Saxon England and present this research in a wellstructured and engaging report." To incorporate the work on Evoke, a further learning outcome was introduced: the ability to "search for, process and analyse information on Old English language and culture from printed and electronic sources." With the Dictionary of Old English Corpus (DOEC), the Toronto Dictionary of Old English (DOE), as well as the online Bosworth and Toller (Bosworth-Toller), A Thesaurus of Old English (тов), Fontes Anglo-Saxonici (Fontes), and Prosopography of Anglo-Saxon England (PASE), the study of Old English is well provided for by electronic tools, and Evoke, therefore, fits in seamlessly with the electronic teaching and research aids which are on offer. The setup of the module allowed for six Evoke assignments for weeks two to seven and an introductory session for the second half of the first week.

This introductory session consists of two parts. First, in order to work fruitfully with Evoke, it is essential for students to have a basic knowledge of lexical semantics: notions such as word fields and semantic fields, the concepts of homonymy and synonymy, and the distinction between hypernyms and hyponyms, are the elements from which a thesaurus hangs together. ${ }^{5}$ With lexicography and lexical semantics not always at the forefront of linguistic teaching, this can be an interesting experience for students and instructors alike, not least because it allows students to conduct research into texts on a methodological basis. The first part of my introductory session was, therefore, dedicated to the principles of lexical semantics, with the examples from Ælfric's Glossarium as a way of showing how medieval glossographers dealt with the same problems as today's students of lexicology and lexicography.

The second part consisted of an introduction into Evoke and aimed to teach the utilisation of the programme with the help of increasingly complicated

5 Hughes (2000: 1-64) contains an accessible introduction to "The Vocabulary as a Historical Repository". For a shorter, but also very useful introduction, see Crystal (1997: 100-107). 
search assignments. ${ }^{6}$ I started out with simple instructions, asking students to navigate the programme and therewith a semantic field. I started out with such assignments as:

- Open Evoke, select a Thesaurus of Old English, explore <all>. We see 18 semantic categories; ${ }^{7}$

- Go to $<$ Creation $>,<$ Humankind $>$, $<$ People $>$, $<$ Female person, woman $>$;

- Then select $<$ open $>$.

The result is a list of ten lexemes, three of which occur only in poetry and two of which are rare (see Figure 2).

If one then asks the students to do the same with 'male person, man', the list yields twenty-five lexemes, nine of which are poetic and two again are rare. A closer inspection of the lexemes and a comparison of these lists raise many questions for students as yet unacquainted with Old English poetry, and some students voiced their disappointment that Evoke did not immediately provide

all $>$ OCreation $>$ o Humankind $>$ O People $>$ o Female person, woman
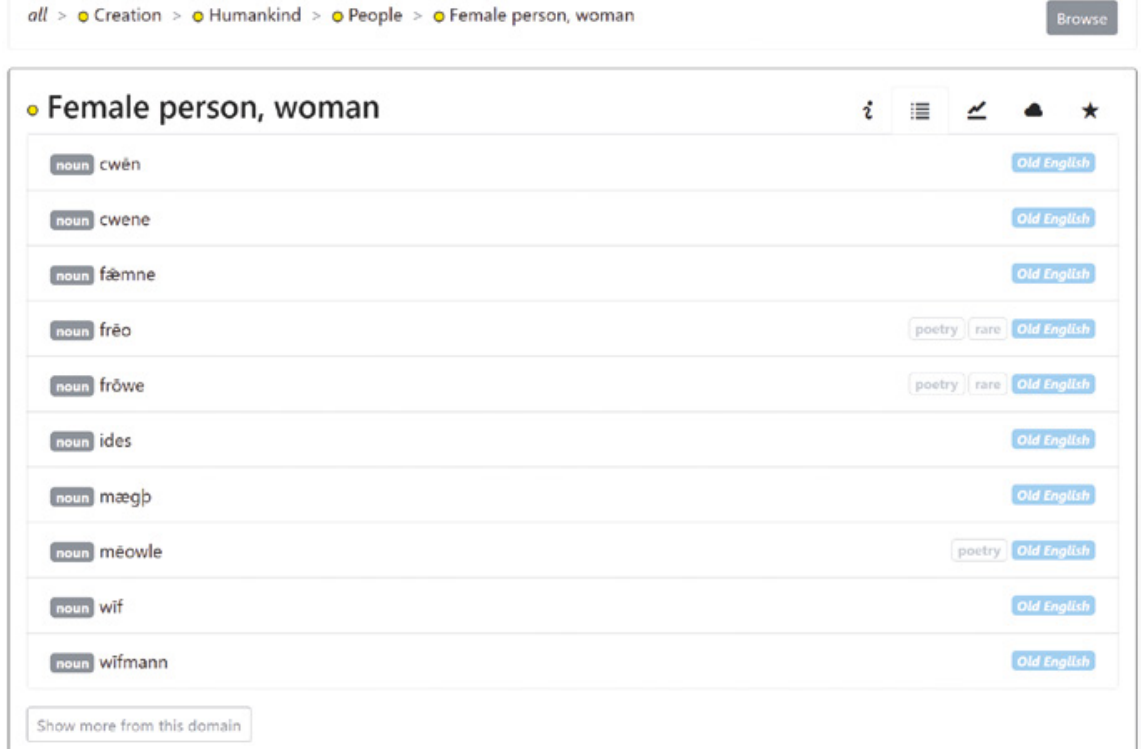

FIGURE 2 Lexemes in TOE category "O2.03.01.02 Female person, woman" in Evoke

6 Such an introduction should ideally take place in a computer lab with all students having access to a terminal on which the programme is installed. In my case, this was impossible, but I had asked students to bring a laptop if they had one, and I must say that this worked remarkably well, with students sometimes working in pairs.

7 For more advanced students, a reference to Roget's International Thesaurus (ed. Kipfer, 2019) would be useful. See also Roberts and Kay (2017), who explain that the conceptual thinking behind these categories go back to Wilkins (1668). 
answers to the questions of why certain lexemes were rare or used only in poetry, while others seemed to be more widespread or featured in different lexical and generic domains. The ensuing discussions provided an excellent opportunity to explain (a) how Evoke can be used as tool to help them answering such questions by means of $T O E$, and (b) how the results of their initial investigations invite further explorations into lexemes and texts. Similar word fields can easily be selected and discussed in an introductory session.

\section{Developing Assignments for Evoke in the Old English Classroom}

The next challenge is to send the students on their way with assignments that are not only interesting and challenging, but also instructive and feasible. Asking too much at this stage is as off-putting as asking too little. As a guideline for the construction of assignments, I used Bloom's Taxonomy of the Cognitive Domain (see Figure 3), which has been a basic principle of teaching theory since 1956, although the list has since then been reworded and reformed, going from six to seven stages by adding "creation" on top of "evaluation" (Bloom et al., 1979; Anderson and Krathwohl, 20o1; Krathwohl, 20o1).

\section{Bloom's Taxonomy \\ (verbs for use in learning outcome statements)}

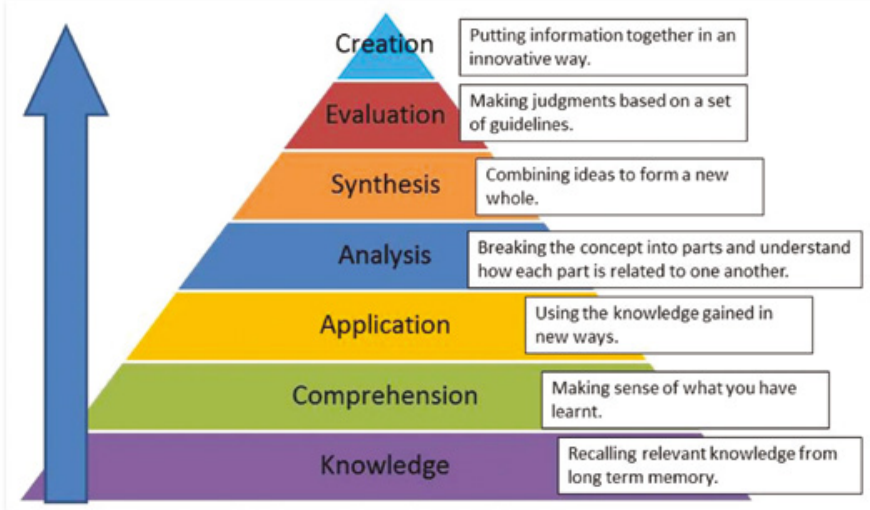

FIGURE 3 Bloom's Taxonomy NIST6DH (CC BY-SA 2.0), HTTPS://AFOCUSONLEARNING OUTCOMES.WORDPRESS.COM/RESOURCES/BLOOMS/ 
The stages of the taxonomy are highly suited for conceptualising assignments with increasing complexity. One may just ask for knowledge in the form of Old English words with the aim of storing them, or require comprehension by reviewing semantic fields. ${ }^{8}$ Such knowledge may be applied to other texts or other themes or be used to analyse and, ultimately, create new views of the Old English lexicon. Bloom's taxonomy complements a tool such as Evoke, which produces data with the possibility of rearranging them in accordance with the demands set by the questions.

The first assignment for the students was linked to their translation text for that particular week and was designed to list terms and learn to search. The text was 'The Fisherman' from Ælfric's Colloquy of the Occupations, in which a fisherman informs an interlocutor of his methods of fishing and his catch, listing in the process the names of his tools as well as eight species of fish and shellfish and the word 'whale.' Together with its companion pieces ('The Monk', 'The Shepherd,' 'The Oxherd,' 'The Hunter,' 'The Fowler,' 'The Merchant', 'The Shoemaker,' 'The Salter', 'The Baker' and 'The Cook'), 'The Fisherman', as printed by Mitchell and Robinson, derives from Henry Sweet's adaptation and simplification of Old English glosses to a Latin colloquy in London, British Library, Cotton Tiberius A. iii, 6ov-64v (ed. Garmonsway, 1978; Mitchell and Robinson, 2012: 190). Like class glossaries, such colloquies emerged from late antique schools. While the form of colloquies changed with the different languages that were taught (Greek, Latin, Old English), their essential function remained the same, in that they were meant to teach not only conversational communication skills, but also vocabulary, and thereby joined forces with the more itemising presentation of vocabulary in class glossaries (Gwara and Porter, 1997: 15-19). By revising the Colloquy for a modern audience of students of Old English, Sweet followed in the footsteps of Ælfric and others before him, who had adapted colloquies as didactic instruments to meet the needs of new generations of students. While in the century or so after Henry Sweet, Ælfric's Colloquy of the Occupations became an elementary translation exercise, the use of Evoke in the study of this text restores for modern students its original function as a resource of interesting vocabulary which may now be studied with modern tools and with new questions. As a first step, therefore, I used Ælfric's Colloquies and Evoke to teach students how fish are arranged in the TOE (a mixture of Bloom's Knowledge and Comprehension). The steps were as follows:

- Open Evoke, select Thesaurus of Old English, <All>;

8 There are many education websites with advice on which verbs to use in order to reach certain cognitive levels. See, for example, Shabutara (27-09-2013). 
- Navigate through the Thesaurus by selecting $<$ Creation $>$, $<$ Animal $>,<$ Fish $>$, $<$ Seafish $>,<$ Particular sea fish (alphabetical order) $>$.

- Select <Flounder, fluke $>$; then select $<$ open $>$, and write down the Old English word for 'Flounder, Fluke'.

- Go back to <Particular sea fish (alphabetical order)>;

- Select $<$ Herring $>$, and write down the Old English words.

- Do the same for the other Sea fish.

- Then go back to $<$ Creation $>,<$ Animal $>,<$ Fish $>$, and select $<$ River fish, freshwater fish $>,<$ Particular fish (alphabetical order) $>$.

- Find the various Old English words for each of the freshwater fish.

- Describe how your list compares to the fish names in the Colloquies on the Occupations?

This exercise asks for simple navigation and a comparison with the text translated in this particular week. However, there were already interesting observations in the answers which showed the curiosity of the students. "Were whales fish in the eyes of the Anglo-Saxons, or did they form a separate category? Catching a whale was too risky for the fisherman, but at the same time there is no mention of a whale not being a fish. Why does Evoke make a distinction between sea fish, freshwater fish, and shellfish, while the fisherman lumps them all together?"' Looking up sea animals triggered questions about classification, or, in Bloom's terms, asking for Knowledge led to questions about Comprehension and Analysis. In class, I then referred to Byrhtferth of Ramsey's Enchiridion where it is stated that God created "eall wyrmcynn and creopende and fleogende and swymmende and slincgende and pa myclan hwælas and pa lytlan sprottas and eall fisckynn on myslicum and mænigfealdum hiwum" [all species of serpents, and creeping, flying, swimming and slinking creatures, and the great whales and the little sprats and all species of fish, in various and manifold shapes] (ed. and trans. Baker and Lapdige, 1995: 72-73), and linked that to the eleventh-century Antwerp-London Glossary, where the whale (no. 2619) occurs under nomina piscium with the dolphin, the salmon, the perch, the trout and the crab, as sea animals (ed. Porter, 2011: 121). Ultimately, the exercise pointed the students to the role of the account of God's Creation in Genesis I and II in the classification of animals.

The following week, the students translated a part of Ælfric's Life of St Edmund. As the events in this text revolve around Edmund's martyrdom, I asked the students to use Evoke to find the Old English words for 'martyr' and key aspects of martyrdom..$^{10}$ This time the assignment offered less guidance, in

9 Citations from the students' work in this article have been kept anonymous and may have been altered to fit the text in which they are embedded. 
order to test whether students had familiarised themselves with the structure of the database.

- Find the Old English word for 'martyr' by browsing the hierarchy in Evoke from the top. First select the category $<$ The extrasensorial world $>$, then $<$ Religion $>$, <Worship, honour, praise $>$, $<$ Martyrdom $>$, and lastly $<$ A martyr $>$. Open it and view its contents. What were the Old English words for 'martyr'?

- Go up one step to <Martyrdom>. List four aspects of martyrdom/the veneration of martyrs anchored in the Old English vocabulary. Mention the relevant words in your descriptions.

The answers prompted some of the students to use the online Bosworth-Toller to work out their findings. Explaining the lexemes prowere and cypere, one student added that:

Secondly, bearing testimony of God is an aspect of being a martyr. Cypere also literally is 'a witness' (Bosworth-Toller), making the martyr a witness who testifies on behalf of God through the devotion of his or her life to God.

Being a witness and giving testimony requires spectators or an audience. This is also reflected in other words in Evoke under the category 'martyrdom', namely prowung, 'anniversary of a martyr's death', and martyrracu, prowingreding 'narrative about martyrs', showing that the martyrs were celebrated and that their stories were openly told. Likewise, the torture of martyrs was public. The word for 'place of martyrdom, amphitheater', witehus, is an 'amphitheater in which the Christians were martyred' (Bosworth-Toller) or literally a 'punishment-house'.

This answer indicates that students who are interested and inquisitive find in Evoke a structured basis for further research. With Evoke and with the help of a dictionary, they are able to map out a cultural concept and apply that concept to what they have read and translated. Asking for categorisation forces students to think of why the semantic field is structured as it is. Even students who put in less work came up with four concepts of martyrdom, and the results could easily be discussed in class, either in a plenary format or in group work.

The next Evoke assignment was based on a theme rather than an individual translation. The theme involved the question of how the Anglo-Saxons conceptualised language and was based on my reading of Suzan Oosthuizen's The Emergence of the English (2019) and Jean Manco's The Origins of the Anglo-Saxons (2018), both deconstructions of the traditional concept of Anglo-Saxon identity. An assignment like this is more complicated than one based on a translation text and, therefore, requires an introduction in class 
before the assignment is set. After the introduction, the student were presented with the following questions:

- There has been a lot of discussion about the status of Old English as a language in the early Middle Ages. How did the Anglo-Saxons conceptualise language? Did they make distinctions between one's own language and a foreign language? Is there a distinction between terms for language or languages with positive and negative connotations?

- Open Evoke and search for $<$ Language $>$; select $<$ A language $>$. List the terms and subordinate concepts.

- Select <leeden >, then select <list> and look at 'the various senses of the current word form'. Do this for all the other terms in the list of terms and subordinate concepts of $<\mathrm{A}$ language $>$. What are the different notions (fields of denotations and connotations) connected with 'language'. Can you say anything about the concept of 'language' in Old English'?

- Go back to <A language $>$ and select <Particular languages $>$. Inspect the terms and subordinate concepts. Could you suggest different subcategories for the terms in the list?

Drawing on the cognitive domains of "application" and "analysis", this question is more open than the previous ones and gives the students a greater opportunity to investigate and, perhaps, suggest rearrangements of the lexemes. That the question struck a chord with students appeared from the length of the answers I received - up to three pages long - with some students copying more than a hundred words and meanings to support their comments. Some students concluded that terms such as tunge, gereord and gesprcec "related to the production of language, with its meaning emphasizing the oral quality of speaking, talking, speech and voice". Most pointed out that Latin was allimportant and constituted a category of its own: loeden not only meant 'Latin tongue' (Bosworth-Toller), but it was also associated with bocleeden, which is 'literary Latin' or 'book-Latin'. Other semantic distinctions featuring prominently in students' answers included academic versus vernacular (folcisc); spoken versus written; poetry versus non-poetic forms. Some students picked up on the various senses of the word twispreece, 'double tongued', which featured in the domains 'bilingual', 'lying, false, not truthful' and 'flattering', and wondered what the significance of this association meant for people who were bilingual or multilingual.

The class discussions, comments and questions concerning the previous Evoke assignment almost automatically led to the next one, in which Evoke was used to question the notion of 'foreign' in Old English." 
- The Anglo-Saxon sense of 'the Other', as opposed to 'the Us' or 'the Self' is partly represented by the modern semantic concept of 'foreign'. The question of what was 'foreign' on an island where five languages were in use, and where the group that has been regarded as dominant prided itself on its origins from across the sea, is difficult to answer.

- In Evoke, search for 'foreign', which will give you the first ten results; select $<$ Foreign $>$ and look at the semantic string from $<$ all $>$ to $<$ foreign $>$. Then Select $<$ Browse $>$ and note the different subfields. Which words fall under these subfields? To check this out, click on a subfield, then click on <open $>$ and note the word. Do this for all four subfields.

- Then go back to $<$ foreign $>$, and select $<$ list $>$. Select each of the sixteen words in turn and then select $<$ list $>$. Which terms have extra connotations, and what are these connotations?

- Based on your findings, add your own classificatory terms in the $<$ Add your own \#annotation> box in the form of a term preceded without a space by a \#.

- When you have finished, click on the black figurine next to the search box and backup your local data file which you can share with others.

- Which classificatory terms did you allocate to the words denoting 'foreign' and why? Comment on what you have learned.

Again, all students accessed and processed a fairly large amount of data on which they based their questions and conclusions.

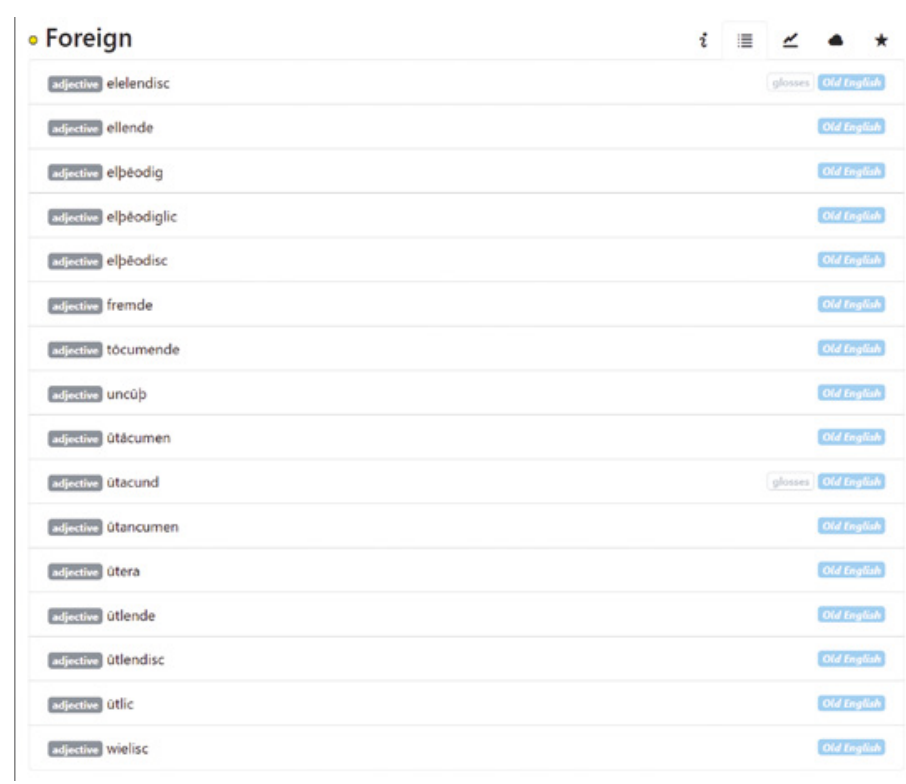

FIGURE 4 Lexemes in TOE category “12.06.05|04 Foreign” in Evoke 
As could be expected from such a broad assignment, the comments varied substantially, but contained many interesting observations. For instance, one student wrote:

Furthermore, I noticed that they [the terms under investigation] had negative connotations in regards to the unknown or foreign. However, 'foreign' is also related to the marvelous or miraculous. Again from these entries the emphasis on kinship can be noted. Also, I find it interesting that British/Welsh/Breton fall under the foreign category while to us they are actually the indigenous peoples. It makes me wonder then who did they consider indigenous, instead.

Other submissions, such as the one below, distinguished elpeodig, 'from another nation', from barriers such as distance, water and speech.

TABLE 1 A student response to the Evoke assignment about foreignness in Old English

\begin{tabular}{ll}
\hline Concept & Words \\
\hline Foreign, distant & - elpeōdig \\
Foreign, from afar & - feor(ran)cumen \\
& - feor(ran)cund \\
From over the water & - ofersǣlic \\
& - ofersǣwisc \\
With other speech & - elreord \\
& - elreordig \\
\hline
\end{tabular}

This shows that the Anglo Saxons might have differentiated between where these foreign parts exactly are in relation to themselves. However, it is then rather funny that they would also distinguish a group as 'from over the water', because every other land is 'over the water' for them.

Another student focused on the negative connotations surrounding the concept of 'unknown': "As 'unknown' seems to carry such negative connotations, I would say that even though many languages existed side by side at the time, people generally had little knowledge of others, which can lead to misunderstanding and resentment." It was interesting and rewarding to see the variation in answers to these assignments and the degree of interest in Old English vocabulary and into the shades of meaning of vocabulary. 
The question that remains to be answered is whether Evoke is an asset to a module which does not have the use of Evoke as its primary learning objective, while Evoke is not primarily a teaching tool. A request to the students for feedback produced positive reactions, such as:

I thought that the Evoke assignments were very interesting. I could really see how words could become a source of cultural information, something I had not thought of that much myself. Assignment $4 \mathrm{~b}$, for example, showed me how the concept of 'language' was associated with both social and political notions, demonstrating how the Anglo-Saxons thought about language.

I liked the assignments and I liked the fact that it was a very new experience in the learning of Old English. I would have loved to follow an entire course on the etymology of Old English, rather than just some assignments. This latter idea is also part of the feedback I would like to give, namely that I would personally like more of a mix of the grammar and etymology.

I liked being able to draw abstract conclusions using the context given by Evoke, rather than the context and content of a primary source. Especially when it came to the categories of words and what these might have meant to the Anglo-Saxons.... Also, I ended up using Bosworth \& Toller online quite a bit, so I would encourage the combined use of a dictionary with Evoke.

Most importantly, these students were able to pinpoint what they had learned and what they wanted to learn. Their positive reactions raises the questions of what Evoke may add to the teaching of Old English, and what we could do to facilitate and optimise it? Two additions to the platform and to the material that is already available would greatly facilitate its use in the classroom. First, a set of instructions for students explaining the utilisation and navigation of Evoke would greatly benefit students and help instructors. Next, the platform's utility for the classroom would be improved by a repository of questions and assignments shared by instructors interested in the use of Evoke for curricular and research purposes.

Finally, three conclusions can, in my view, safely be drawn. For one, the Evoke assignments allow students to proceed with and improve on accepted methodologies and facilitate the use of electronic corpora by future generations of 
students. Moreover, since it is, essentially, a research tool, Evoke is also a way of demonstrating to students how teaching can be linked with research. Using such tools as Evoke can make the students realize that research is within their reach, and that they can be at the controls. Lastly, Evoke is certainly a way of bringing philology to the foreground. Working from translation has almost become the norm in the teaching of Old English literature. In 2002, Teaching Beowulf in Translation (ed. Ramsey, 2002) saw the light, and Craig Williamson's The Complete Old English Poems, which came out in 2017, lists among its praises on the back cover that "the earliest English verse has never been such a delight to read." ${ }^{2}$ While this is probably true for most general readers, it is highly important that students of English are made aware of the fact that for a good understanding of Old English literature, their knowledge of Old English and the history of the English language are essential. Working with Evoke may help us to keep the link between language, text and culture vital, by inviting students to explore the meaning of Old English vocabulary with the help of questions for which there is not a pre-fabricated answer.

\section{References}

Anderson, L. W., and D. R. Krathwohl. A Taxonomy for Learning, Teaching, and Assessing: A Revision of Bloom's Taxonomy of Educational Objectives (New York: Longman, 2001).

Anlezark, D. "The Anglo-Saxon World View." In The Cambridge Companion to Old English Literature, 2nd edn, eds. M. Godden and M. Lapidge (Cambridge: Cambridge UP, 2013), 66-81.

Anlezark, D., ed. and trans. Old Testament Narratives, Dumbarton Oaks Medieval Library 7 (Cambridge, MA: Harvard UP, 2O11).

Baker, P. S., and M. Lapidge, ed. and trans. Byrhtferth's Enchiridion, EETS s.s. 15 (Oxford: OUP, 1995).

Bloom, B. S., et al. Taxonomy of Educational Objectives: The Classification of Educational Goals. Handbook 1. Cognitive Domain (London: Longman, 1979).

Bosworth-Toller $=$ Bosworth, J. An Anglo-Saxon Dictionary Online, eds. T. N. Toller, C. Sean, and O. Tichy (Prague: Faculty of Arts, Charles University, 2014), https:// bosworthtoller.com/.

12 R. D. Fulk's full citation on the back of the dust jacket is as follows: "It is cause for celebration to have at last a translation of the entire Old English poetic corpus, moreover a rendering that is discerning, nuanced, and poetically crafted. The earliest English verse has never been such a delight to read." While all praises of Williamson's translations are completely justified, it is also important to realise that the use of translations in teaching deflects the attention from the original texts. 
Codoñer, C., ed. and trans. Isidoro de Sevilla. Diferencias, libro I. Introducción, Edición Crítica, Traduccióny Notas, Auteurs Latins du Moyen Âge 8 (Paris: Les Belles Lettres, 1992).

Crystal, D. The Cambridge Encyclopedia of Language, 2nd ed. (Cambridge: Cambridge UP, 1997).

Dionisotti, C. "From Ausonius' Schooldays? A Schoolbook and Its Relatives." The Journal of Roman Studies 72 (1982), 83-125.

$D O E=$ Cameron, A., A. C. Amos, A. diPaolo Healey, et al. Dictionary of Old English: A to I Online (Toronto: Dictionary of Old English Project, 2018), https://tapor library.utoronto.ca/doe/.

$D O E C$ = DiPaolo Healey, A., with J. Price Wilkin and X. Xiang, ed. Dictionary of Old English Web Corpus (Toronto: Dictionary of Old English Project 2009), https:// tapor-library-utoronto-ca/doecorpus/.

Evoke = Stolk, S. Evoke (Web application, 2018), http://evoke.ullet.net/.

Fontes = Fontes Anglo-Saxonici: World Wide Web Register (1984, revised version 2021), https://arts.st-andrews.ac.uk/fontes/.

Garmonsway, G. N., ed. Elfric's Colloquy, 2nd edn (Exeter: University Printing Unit, 1978).

Godden, M., and M. Lapidge, eds. The Cambridge Companion to Old English Literature, 2nd edn (Cambridge: Cambridge UP, 2O13).

Gwara, S., and D. W. Porter, eds. Anglo-Saxon Conversations: The Colloquies of Elfric Bata (Woodbridge: Boydell, 1997).

Hughes, G. A History of English Words (Oxford: Blackwell, 200o).

Kipfer, A. B., ed. Roget's International Thesaurus, 8th edn (New York: Harper-Collins, 2019).

Krathwohl, D. R. “A Revision of Bloom's Taxonomy: An Overview." Theory into Practice 41 (2001), 212-18.

Lapidge, M. "The Saintly Life in Anglo-Saxon England." In The Cambridge Companion to Old English Literature, 2nd edn, eds. M. Godden and M. Lapidge (Cambridge: Cambridge UP, 2013), 251-272.

Lendinara, P. "Anglo-Saxon Glosses and Glossaries: An Introduction." In Anglo-Saxon Glosses and Glossaries, ed. P. Lendinara, Variorum Collected Studies 622 (Aldershot: Ashgate, 1999), 1-26.

Manco, J. The Origins of the Anglo-Saxons (London: Thames and Hudson, 2018).

Mitchell, B., and F. C. Robinson. A Guide to Old English, 8th edn (Malden, MA, Oxford: Wiley-Blackwell, 2012).

Oosthuizen, S. The Emergence of the English (London: AHC Humanities Press, 2019). PASE = Prosopography of Anglo-Saxon England (London: King's College, 2010), https:// pase.ac.uk/index.html. 
Porter, D. W., ed. The Antwerp-London Glossaries: The Latin and Latin-Old English Vocabularies from Antwerp, Museum Plantin-Moretus 16.2 - London, British Library Add. 32246 (Toronto: Pontifical Institute, 2011).

Ramsey, M. K., ed. Beowulf in Our Time: Teaching Beowulf in Translation, Old English Newsletter Subsidia 31 (Kalamazoo: Medieval Institute Publications, 2002).

Shabutara, J. "Using Bloom's Taxonomy to Write Effective Learning Objectives" (Fayetteville: University of Arkansas, TIPS, 27-09-2013), https://tips.uark.edu/using -blooms-taxonomy/.

TOE = Roberts, J., and C. Kay with L. Grundy. A Thesaurus of Old English (Glasgow: University of Glasgow, 2017), https://oldenglishthesaurus.arts.gla.ac.uk/ introduction/.

Wilkins, J. An Essay towards a Real Character and a Philosophical Language (London: S. Gellibrand and J. Martin, 1668).

Williamson, C., trans. The Complete Old English Poems, with an introduction by T. A. Shippey (Philadelphia: University of Pennsylvania Press, 2017).

Zupitza, J., ed. Elfrics Grammatik und Glossar (Berlin: Weidmann, 1880). 